\title{
Tanulmány
}

\section{Anita Kiss \\ A comparative analysis about the language attitude of Transcarpathian-Hungarian students with matched guise technique}

\begin{abstract}
In my treatise, I analysed the attitudes in connection with the Hungarian use of language in Transcarpathia with matched guise technique. During the survey, I compared the language attitudes of Transcarpathian-Hungarian students, who study in tertiary education in Hungary or in Transcarpathia. In my research, the participants were asked to listen to two recordings. One of the recordings contained words borrowed from Russian and Ukrainian languages, which is typical in the Transcarpathian-Hungarian use of language. In the other text, these borrowed words were replaced with their Hungarian equivalents. My research was based on the hypothesis that the students will prefer the language use of the agent in the Hungarian version. Moreover, I assumed that the college students of Transcarpathia will evaluate the agent speaking in the Transcarpathian version more positively than the Transcarpathian-Hungarian students, who study in Hungary. According to the results, both group of participants preferred the agent speaking in the Hungarian version.

Keywords: bilingualism, linguistic attitude, borrowing of words, matched guise technique.
\end{abstract}

\section{Introduction}

Numerous examinations have already been carried out amongst Hungarians living in Transcarpathia about the judgement of the local use of Hungarian language, all of which showed a positive attitude towards this language variant. These examinations were mostly based on inquiries (compare Csernicskó 2008, Dudics Lakatos 2015, Karmacsi 2009, Lakatos 2006, T. Károlyi 2002). To present the results of my research, I applied the so-called matched guise technique, which is less widespread in Transcarpathia. The first examination with this method can be read in the research paper of Wallace Lambert et al. (1967), which was developed for the analysis of attitudes towards different language variants. To choose the proper alibi is an important part of matched guise technique. It helps to divert the participants attention from being part of a linguistic experiment, therefore we can get a more realistic picture about their language attitudes.

During the examination the participants were asked to listen to two recordings. One of the recordings contained words borrowed from Russian and Ukrainian languages, which is typical in the Transcarpathian Hungarian use of language. In the other text, these borrowed words were 
Anita Kiss:

A comparative analysis about the language attitude of Transcarpathian-Hungarian students

with matched guise technique

Argumentum 18 (2022), 1-16

Debreceni Egyetemi Kiadó

DOI: 10.34103/ARGUMENTUM/2022/1

replaced with their Hungarian equivalents. After listening the recordings, the participants were asked to fill in a questionary, in which different personal features were listed. The participants had to mark on a 5-point scale that in what extent those characteristics could be suitable for the speaker.

The aim of the research was to examine the attitudes of college and university students towards the words borrowed from Ukrainian and Russian, which is a typical feature of the Transcarpathian-Hungarian use of language. I was looking for the answer, which language variant is preferred by the Transcarpathian-Hungarian students: the Transcarpathian or the Hungarian version.

\section{The definition of language attitude}

The general meaning of attitude: mindset; behaviour; manner; the way, how someone deals with something like a phenomenon or opinion. Cseresnyési defines attitude the following way: stable attraction or aversion, positive or negative relation to people, situations, ideas, and an emerged inclination to qualify something consistently good or bad (2004: 124).

The knowledge and beliefs in connection with language is called language attitude, in which a particular person's or group's terms and judgements are expressed connected to certain languages, language variants, pronunciation variants and any linguistic phenomena. Attitude can be located on a scale from very positive to complete rejection, which appears in judgements about the 'correctness' and value of a language as well as the speakers' personal characteristics (Grin 2013, Trudgill 1997). In connection with language attitudes there are two approaches: behaviourist and mentalist. According to the behaviourist approach, attitude is an answer or behaviour given to particular social situations and can be examined through the observation of behaviour and the interpretation of experiences (Agheyisi \& Fishman 1970, Domonkosi 2004). According to the mentalist approach, attitude cannot be observed directly, it can only be inferred based on the individual's oral, behavioural or emotional reactions. This approach considers attitude an inside standby condition, which establishes connection between opinion and behaviour. According to the mentalist approach, attitude structurally contains three elements, and these have a common effect on the formation of attitude: cognitive, evaluative and conative. The cognitive element means all the knowledge connected to the particular phenomenon. Through the evaluative component emotions are connected to particular knowledge and beliefs, and when emotions are connected to beliefs it forms prejudice in a positive or negative way. The third, conative element is determined by the previous two components, knowledge, beliefs and emotional values connected to these are transformed here into particular behavioural preparedness, which means the potential behaviour in connection with the attitude-object (Kiss 1995). These three elements point out the relation between the individual's thoughts, acts and emotions, however, we cannot draw an obvious conclusion from the language behaviour, because it can be influenced by the circumstances and the fact that the speaker tries to adapt to the assumed language expectations of the conversational partner. Language attitude exists in personal as well as in social contexts, therefore it can express group identity, togetherness or even separation from a group (Domonkosi 2004).

Language attitudes originate in societies, not in languages, consequently they express social habits, behavioural rules and prejudice instead of linguistic or aesthetic values. Sociolinguistic research brought to light that language attitudes are formed as the confirmation and validation 
Anita Kiss:

A comparative analysis about the language attitude of Transcarpathian-Hungarian students

with matched guise technique

Argumentum 18 (2022), 1-16

Debreceni Egyetemi Kiadó

DOI: 10.34103/ARGUMENTUM/2022/1

of an earlier created not language related stereotype (Kiss 1995). Therefore, language attitudes can have an influence on the changes of the language, behaviour, and can cause insecurity in language use, which means that the users of the language show antipathy towards their language variant, in other words they question its 'correctness'. They try to acquire a speaking style, which is in a higher status, and it can lead the individuals to overcorrection and the groups to overachievement of norms (Trudgill 1997). According to Klára Sándor, we have a negative relation with the groups in which the language form is used and not with the language form itself. Therefore, our language attitudes do not refer to the language, but rather the groups and individuals behind it. It can even refer to the individual's language use in case someone is ashamed of it because of an offense. In this case this person tries to keep distance from that group and move towards a standardized language style (Sándor 2016).

\section{Examinations of language attitudes of Transcarpathian-Hungarian students}

We know it from a Transcarpathian research that in language exchange and language retention the attitude of language users towards the language variant of their community is important. The research results showed that the participants judged their community and the language variant used by them positively. According to the majority of participants, the Hungarian use of language sounds the most beautifully in Transcarpathia (Csernicskó \& Soós 2002).

In order to find out what role mother tongue plays in forming identity, between 2003 and 2008 surveys were carried out amongst young adults between the ages of 15 and 29 . According to the participants, mother tongue is an important factor of national identity. Those participants, who live in a settlement, where language exchange is at an advanced stage had a similar opinion as well (Csernicskó 2008).

In 2006 empirical research was carried out about the prestige of the Hungarian, Ukrainian and Russian languages, involving 300 Transcarpathian-Hungarian participants. In the result of the research, it turned out that each of the participants likes to speak in Hungarian. Moreover, they rated the languages on a 10-point scale, and they considered Hungarian very beautiful ( 9.63 points), they think Russian sounds a bit better than the average ( 6,84 points) and Ukrainian is only thought to be on a moderate level. As for their mother tongue, according to two-thirds of the participants the most beautiful Hungarian use of language is in Transcarpathia, and only $10 \%$ has the opinion that it is in Hungary. So, all in all, they have a positive attitude towards their native language (Karmacsi 2009).

Katalin Dudics Lakatos examined the language attitude of Transcarpathian-Hungarian students. According to the results, the Transcarpathian-Hungarian school children do not prefer speaking in dialects, and it determines their opinion in connection with the language use of their settlement (Lakatos 2006). According to another research, most of the TranscarpathianHungarian children think that dialects are old-fashioned, and it is more typical in the language use of those, who live in their environment than in their own speech (Dudics Lakatos 2015).

Katalin Dudics Lakatos examined the attitudes towards language variants and dialects amongst Transcarpathian-Hungarian teachers as well. The survey was carried out between 2007 and 2008 involving 150 specialised teachers. Ten years later, she reiterated the examination, in order to find out, whether the attitudes of pedagogues changed compared to the previous research. The motivating factor of carrying out the survey again was that the mother tongue education reform came out in 2005 , which transfers the material with an additive approach to 
Anita Kiss:

A comparative analysis about the language attitude of Transcarpathian-Hungarian students

with matched guise technique

Argumentum 18 (2022), 1-16

Debreceni Egyetemi Kiadó

DOI: 10.34103/ARGUMENTUM/2022/1

the 5-12 grades of Hungarian schools. The aim of the reform for teachers was to improve the students' communication competence, furthermore, to educate them about the variety of languages and the characteristics of the Transcarpathian-Hungarian use of language. The results of the research between 2007-2008 showed that the teachers, who were involved, were able to realise the differences between the Transcarpathian and Hungarian use of language, and according to their opinion, it was noticeable mainly in contact effects and dialectical phenomena. The interviewed teachers considered dialects as a legacy and the expression of identity, which factors should be important to keep. Based on the answers we can realise that the teachers recognized that a dialectical form is spoken in their environment, but they still had a reserved attitude towards these dialects. According to the results, ten years later a positive change could be observed after the popularization of the paradigm shift in mother tongue education. Based on the data, teachers became more tolerant with the speakers of on-standard language variants. Many of them answered that they would feel badly for the disappearance of dialects, but in some cases, there were undecided, controversial attitudes towards the judgement of dialectical phenomena (Dudics Lakatos 2019). The effects of the paradigm shift in 2005 could also be noticed in the language attitude of students. The results of a survey, carried out in 2018 showed that the secondary school students, who were involved, became less distant with dialectical speech, and considered this variant as their own, and they also became much more tolerant with the speakers of non-standard language variants, compared to the results of the surveys, which had been carried out 10 years earlier (Dudics 2021).

The surveys above examined the language attitude of Transcarpathian-Hungarians mostly with questionnaires and interviews. However, we can apply other methods as well, about which I write in the following chapter.

\section{$4 \quad$ Methodology for examining language attitudes}

Language attitudes can be examined both directly and indirectly. The methodologies come from sociology, the most typical of which is acceptance or refusal of the evaluating ascertainment by the participants taken in the research. It usually happens with the help of open questions, when researchers ask about knowledge, opinions and judgements (Kožík 2004).

For attitude analysis we have other methodologies as well, depending on which branch of science's methods we follow. In an often-applied procedure by sociopsychology the attitude and reaction of the participant in connection with particular language variants is observed in laboratory conditions. The most widespread version is the attitude-scale which has more possible variants. In the Thurstone- and the Likert-scale participants are asked to form an opinion about different statements. They can agree or disagree, but it is allowed to stay neutral. In another version, which was applied for examining Welsh communities, the participants are also asked to express the level of agreement or disagreement and mark it on a 5-or 7-point scale (Baker 1992).

One of the popular methods of the examination of language attitude is when a text is read by the same person in two different language variants, while the participants are not informed that they heard the same speaker in both versions. This method is called matched guise technique (Cseresnyési 2004). This method was published by Lambert et al. in 1960, and the aim of it was to show the attitudes of speakers towards different language variants. Moreover, this method helped to state, which stereotypes about the speakers of assorted language variants inside a 
Anita Kiss:

A comparative analysis about the language attitude of Transcarpathian-Hungarian students

with matched guise technique

Argumentum 18 (2022), 1-16

Debreceni Egyetemi Kiadó

DOI: 10.34103/ARGUMENTUM/2022/1

language community exist. Originally this method was used for examining the French-English bilingualism in Canada (Lambert et al. 1967), and later it was used in several other studies as well (Giles \& Coupland 1991, Milroy \& Preston 1999). A crucial part of the examination is a (mostly five-, six- or seven-point) scale. One of the ends of the scale demonstrates positive, and the other negative features. The participants are asked to mark the point, which expresses their opinion the most, then these points are turned into numbers by the researchers. The matched guise technique was developed with the help of verbal guise. The difference between the methods is that in the latter the text isn't read by the same agent twice, here there are more readers, who have similarities in their social backgrounds. With the help of this technique, attitudes towards more language variants can be compared (Callan et al. 1983, Gallois \& Callan 1981, McKenzie 2008).

\section{Examinations carried out with the help of matched guise technique}

We can read about the first Hungarian use of matches guise technique in the study of Klára Sándor, Juliet Lagman and Csaba Pléh. Four of the participant groups studied in Szeged and two in Budapest. The research was based on the hypothesis that the speaker of the non-standard language variant will be judged more negatively than the standard speaker, and the participants from Budapest will generally have a less positive opinion about the non-standard speaker. The results showed that the participants from Budapest actually had a more significant prejudice towards the speaker, whose speech they considered dialectal. It also came to light that regardless of the territory, the non-standard speaker is judged less beneficially (Sándor et al. 1998).

Examinations with the help of matched guise technique were carried out over the border as well.

In a Transcarpathian survey (Agent 2000) the participants were asked to listen to four recordings. In the first and fourth ones the speaker was the same, but for the first time he spoke in Hungarian and then in Ukrainian. The secondary school participants were asked to evaluate the agent based on several inner and physical attributes. The results showed that there wasn't any significant difference between the participants' opinions about the agents speaking in Hungarian or in Ukrainian (Beregszászi et al. 2003).

In the research of István Jánk, future and present teachers were asked to evaluate the student's oral performances. During the examination, participants listened to texts in different language variants from various speakers. The aim of the research was to make it clear that which aspects play a more dominant role in the pedagogue's evaluation. It could be the student's theoretical knowledge or use of language which in Jánk's research meant the standard or nonstandard and the limited or unlimited language codes. He started his research with a trial examination, at Nyitrai Konstantin Philosophical University, with 50 participants involved, amongst whom there were early childhood educator and Hungarian language teacher students. According to his hypotheses, the teachers' evaluation is strongly influenced by the basic language of the students. It means that the future teachers gave one grade lower to the students, because they didn't use the standard language variant and well-formed codes, in spite of their perfect knowledge about the current material. Moreover, they evaluated those students more positively, who didn't have a comprehensive theoretical knowledge, but they used the standard language variant during their oral presentation (Jánk 2017, Jánk 2018). Jánk later extended his research to four countries of the Carpathian Basin, and carried out it in Hungary, Slovakia, 
Anita Kiss:

A comparative analysis about the language attitude of Transcarpathian-Hungarian students

with matched guise technique

Argumentum 18 (2022), 1-16

Debreceni Egyetemi Kiadó

DOI: 10.34103/ARGUMENTUM/2022/1

Romania and Ukraine, amongst 502 future or present Hungarian teachers. In all of the groups the same results came to light: in oral presentations with different contents, language variants and uses of language, teachers evaluated those more positively, who used the standard variant and well-formed codes. Those, who spoke in a dialect, or limited code, got a less beneficial evaluation, in spite of the student's perfect knowledge about the material (Jánk 2019).

Anna Fenyvesi observed the language attitude of students from Transylvania, Vojvodina and the southern part of Slovakia with the help of matched guise technique. Six languages or language variants and five speakers were involved in her research (Hungarian; local, regional Hungarian variant, English with Hungarian accent, British English, American English and majority language). Here I only would like to present briefly the results connected to the Hungarian, regional Hungarian and majority languages and language variants. From among the mother tongue variants, Hungarian got the most positive evaluation, the judgements of the regional Hungarian and majority language were approximately the same. Based on territories: in Transylvania the regional Hungarian got more positive judgement, in the southern part of Slovakia it was the opposite, and in Vojvodina the judgements were equal. Attitudes towards the majority language were negative, and the Hungarian language got better judgement than the regional Hungarian variant, while towards the latter solidarity showed positive values (Fenyvesi 2011).

All in all, the results of researches with matched guise technique show that the standard form has a better judgement than the local, regional language variants.

The above presented surveys, which were carried out with the help of matched guise technique, are about the attitudes towards standard and dialectical language variants. In my own research I examined attitudes towards Transcarpathian-Hungarian borrowed words, which are parts of the Transcarpathian regional language variant and supposedly these are also components of the participants' dialects (compare Gazdag 2021).

\section{Research hypotheses}

1. According to the results of the research carried out with matched guise techique, the standard version has a more positive judgement in opposition with the local regional language variants (Sándor et al. 1998). I assume that in relation to the majority of characteristics, both groups of students will prefer the agent in the Hungarian version instead of the Subcarpathian-Hungarian speaker with borrowed words from Ukrainian and Russian.

2. The results of the attitude-research in connection with the Subcarpathian-Hungarian language use showed that those Hungarians, who live in Subcarpathia can make a difference between their own and the Hungarian language variants, and they also consider their own variant better. Moreover, it turned out that those who left their motherland behind, try to adjust their language use to the Hungarian variant during communication (Csernicskó 2008). To this extent I assume that those Subcarpathian-Hungarian college students, who still live in their motherland will prefer the agent speaking in the Subcarpathian-Hungarian variant more than those Subcarpathian-Hungarian university students, who study in Hungary. 
Anita Kiss:

A comparative analysis about the language attitude of Transcarpathian-Hungarian students

with matched guise technique

Argumentum 18 (2022), 1-16

Debreceni Egyetemi Kiadó

DOI: 10.34103/ARGUMENTUM/2022/1

\section{$7 \quad$ Methodology}

In my treatise, I examined the attitudes in connection with the Hungarian use of language in Transcarpathia with matched guise technique. During the survey, I compared the language attitudes of Transcarpathian Hungarian students, who study in tertiary education in Hungary or in Transcarpathia. In my research, the participants were asked to listen to and evaluate two recordings. One of the recordings contained words borrowed from Russian and Ukrainian, which is typical in the Transcarpathian Hungarian use of language. In the other text, these borrowed words were replaced by their Hungarian equivalents.

A survey, carried out with the help of matched guise technique is always based on an alibi. I also tried to divert the participant's attention from being part of a language attitude analysis. Based on the description of the questionary they thought that I wanted to observe, how they evaluate or judge an applicant for a telemarketer job, based on a trial audition. Then, they were asked to listen to the recording of the first applicant and fill in the questionary based on it. The process was online, and I attached the recordings as links. The data collection took place between September and December 2020. On both recordings, the agents are identified by a code, in the Hungarian version it is applicant1, in the Transcarpathian-Hungarian version it is applicant2. For the survey, I made two recordings, but one participant listened to only one of these. The difference between the two recordings, as shown below, is only in the highlighted words.

The participants originally listened to a Hungarian text, which can be read below in Hungarian as well.

\section{Kedves vásárlóink!}

Cégünk az egészség megörzése érdekében olyan termékeket forgalmaz, amelyek kizárólag természetes, gyógynövény tartalmú alapanyagokból készülnek. Kinálatunk nagyon széles. Étrend-kiegészitő vitaminoktól kezdve, ezüstszálas zoknikon át, gyógynövény tartalmú fogkrémig (fogpasztáig [or. зубная паста]) minden korosztály talál a maga számára hasznos terméket. Sokan nem tudják, de leginkább gyógynövényekkel segithetjük szervezetünk ellenálló képességét, ami az ősszel megjelenö influenzajárvány (grippjárvány [or. грипп]) miatt nélkülözhetetlen. Fontos számunkra az ön elégedettsége, ugyanis ha a választott termék nem megfelelö (nem pászol [ukr. пасувати]), esetleg a csomag tartalma gyári hibás (brakkos [or/ukr брак]), visszaküldheti, és mi megtéritjük a vételárat. Bármilyen felmerülö kérdés esetén hívja (csengessen or. позвонить] 'megesenget') ügyfélszolgálatunkat (ügyfélszolgálatunkra).

Hun $=$ Hungarian version

Transc-Hun $=$ Transcarpathian-Hungarian version

rus. $=$ Russian version

ukr. $=$ Ukrainian version

\section{Dear Costumers!}

The goods, distributed by our company are made exclusively from natural, herbal materials. Our supply is especially wide. Including dietary supplement vitamins, silver-fibre socks and herb-based toothpaste (Hun: fogkrém, Transc-Hun: fogpaszta [rus. зубная паста]) every 
Anita Kiss:

A comparative analysis about the language attitude of Transcarpathian-Hungarian students with matched guise technique

Argumentum 18 (2022), 1-16

Debreceni Egyetemi Kiadó

DOI: 10.34103/ARGUMENTUM/2022/1

age group can find the suitable products. It is not well-known, but we can boost our immunesystem mostly with herbs, which is indispensable in fighting against the flu epidemic (Hun: influenzajárvány, Transc-Hun: grippjárvány [rus. грипп]). Your satisfaction is very important to us, so if the chosen product is not suitable (Hun: nem megfelelö Trans-Hun: nem pászol [ ukr. пасувати]) for you, or the package is defective (Hun: gyári hibás TranscHun: brakkos [rus/ukr брак]), you can send it back, and we refund the price. In case of questions, call (Hun: hívja, Transc-Hun: csengessen [rus. позвонить] 'megcsenget') our customer service department.

Altogether 103 Transcarpathian-Hungarian students were involved in the survey. 60 participants study at the University of Debrecen, in the followings, I am going to refer them as UD Students. 43 participants study at II. Rákóczi Ferenc Transcarpathian-Hungarian Collage (in the followings: THC students). I analysed the data of the survey with Microsoft Excel 2016 MSO (16.0.4266.1001) programme, and during the analysis I made individual pattern t-tests.

\section{Results}

The participants' average age is $21.52 \%$ is female and $48 \%$ is male. Most of the participants $(65 \%)$ were born in a village, $28 \%$ in a town, and $7 \%$ in a town-like settlement. Currently, $58 \%$ of the participants live in Debrecen, Hungary, $41 \%$ in Ukraine, from which $21 \%$ lives in a town and $20 \%$ in a village.

The majority of the UD as well as the THC students would like to live in a Hungarian rural town (Graphs 1 and 2).

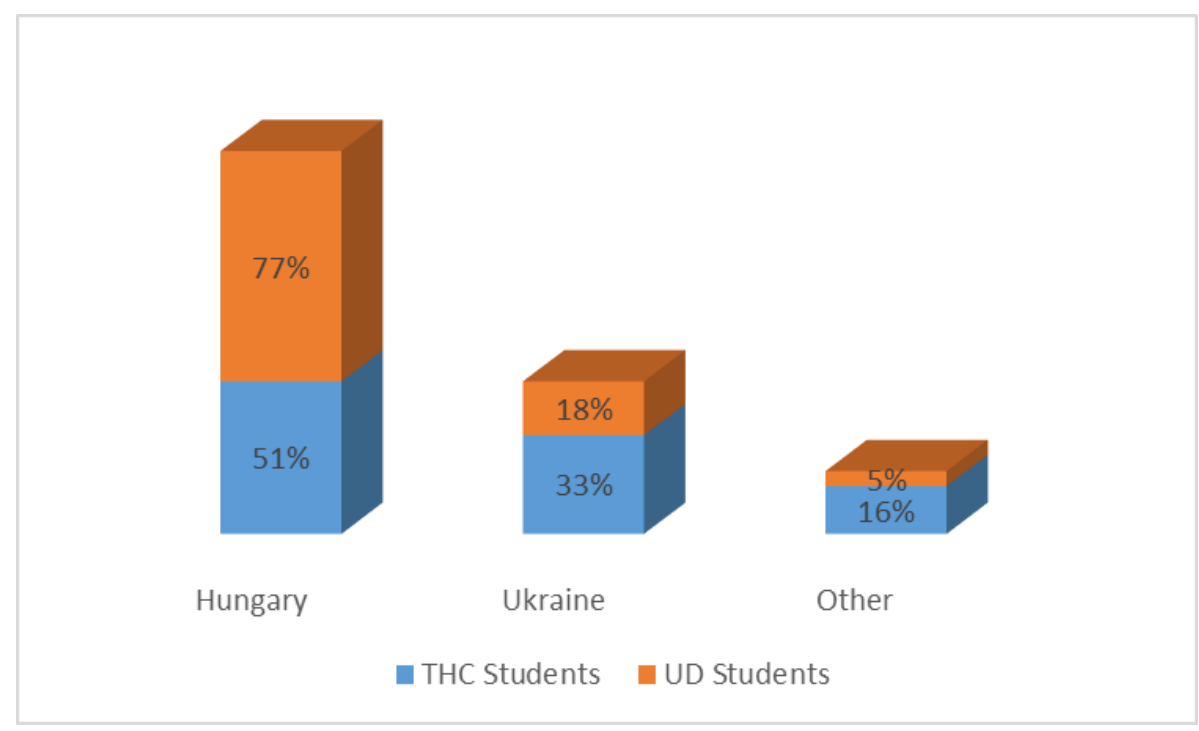

Graph 1. Where would you prefer to live? (1) 
Anita Kiss:

A comparative analysis about the language attitude of Transcarpathian-Hungarian students with matched guise technique Argumentum 18 (2022), 1-16

Debreceni Egyetemi Kiadó

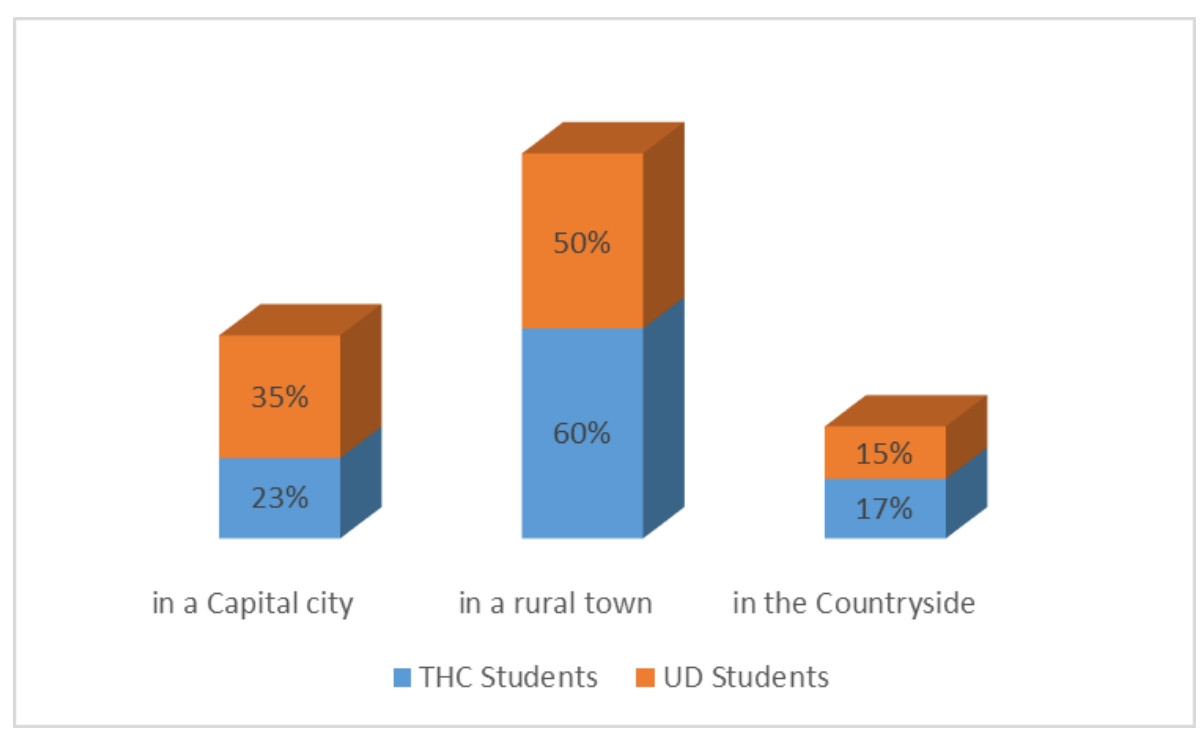

Graph 2. Where would you prefer to live? (2)

Both participant group's opinion was similar in connection with the living place of the agents. Most of the students thought that the agent in the Hungarian variant (applicant1) lives in the capital city of Hungary, while the speaker in the Transcarpathian-Hungarian version (applicant2) lives in a rural town of Ukraine (tables 1 and 2).

\begin{tabular}{|l|c|c|c|c|}
\hline & \multicolumn{2}{|c|}{ THC students (\%) } & \multicolumn{2}{c|}{ UD students (\%) } \\
\hline & Applicant1 & Applicant2 & Applicant1 & Applicant2 \\
\hline Ukraine (Transcarpathia) & 14 & 28 & 5 & 42 \\
\hline Hungary & 35 & 18 & 38 & 3 \\
\hline I cannot decide & 5 & 0 & 5 & 7 \\
\hline
\end{tabular}

Table 1. Where does the applicant come from?

\begin{tabular}{|c|c|c|c|c|}
\hline & \multicolumn{2}{|c|}{ THC students (\%) } & \multicolumn{2}{c|}{ UD students (\%) } \\
\hline & Applicant1 & Applicant2 & Applicant1 & Applicant2 \\
\hline in a capital city & 35 & 6 & 25 & 3 \\
\hline in a rural town & 19 & 28 & 22 & 33 \\
\hline in the countryside & 0 & 12 & 2 & 15 \\
\hline
\end{tabular}

Table 2. Where does the applicant currently live? 
Anita Kiss:

A comparative analysis about the language attitude of Transcarpathian-Hungarian students

with matched guise technique

Argumentum 18 (2022), 1-16

Debreceni Egyetemi Kiadó

DOI: 10.34103/ARGUMENTUM/2022/1

According to most of the students' opinion each agent has a college or university degree, which means the participants do not think that the agent speaking with borrowed words from Ukrainian and Russian is less educated, which refers to a positive attitude (Graph 3).

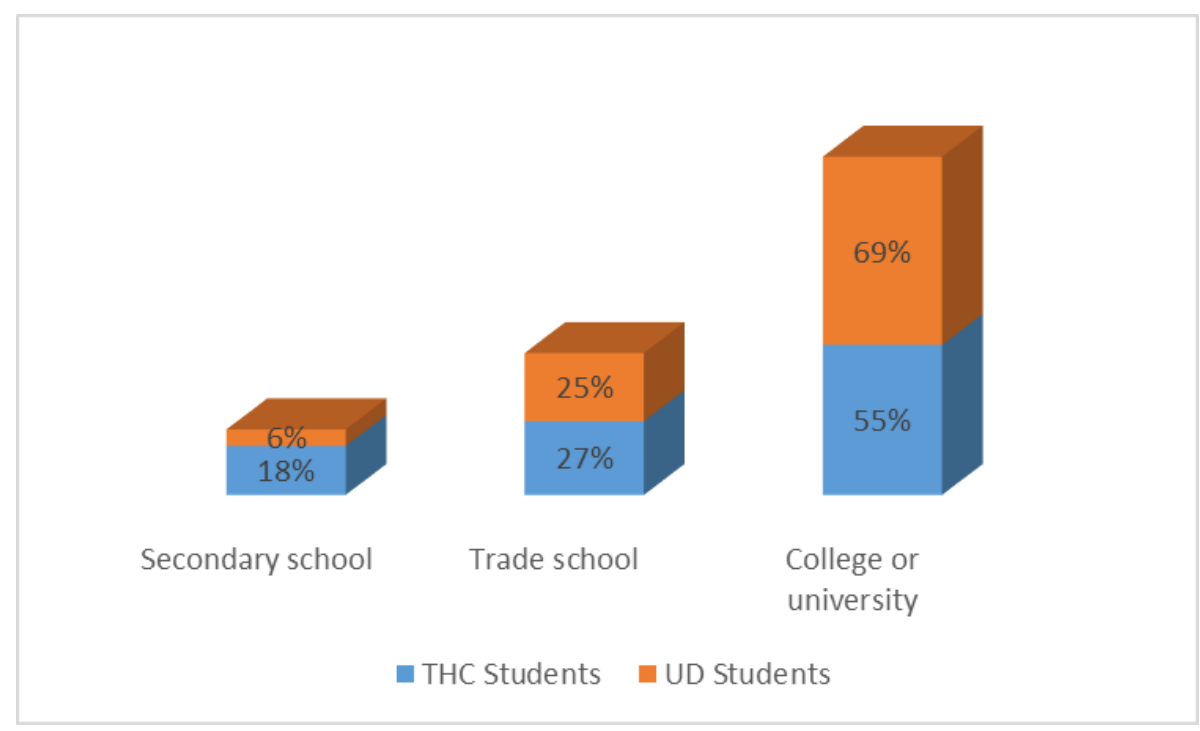

Graph 3. What is the applicant's highest level of education?

In the followings, the participants were asked to evaluate the agents on a 5-point scale. They had to express that in what extent do they consider the agents intelligent/smart, convincing, helpful, kind, friendly, reliable, serious and determined based on the recordings. Moreover, they also had to evaluate the applicant's style of speech/vocabulary, pronunciation, phraseology and tone. Besides, they had to form an opinion about the aptitude of the candidate for the job. In the questionary only the two extreme values were given: $1=\mathrm{I}$ do not agree at all, $5=\mathrm{I}$ agree completely. During my analysis I associated the other numbers with meanings as well, $2=\mathrm{I}$ agree less, 3 = I moderately agree, $4=$ I rather agree.

During the analysis of the data, I used two-sided t-test. In one case the two variants were the two agents or the two applicants. With the help of this examination, I wanted to point out that in connection with which characteristics was there a significant difference next to $p<0,05$ value. Based on the answers of THC students there was a considerable discrepancy between the judgment of the two agents. They evaluated the agent in the Hungarian version smarter/more intelligent $\mathrm{t}(34)=2,96 \mathrm{p}<0,05(\mathrm{p}=0,005)$, more determined $\mathrm{t}(29)=2,09 \mathrm{p}<0,05(\mathrm{p}=0,04)$, and also more suitable $t(26)=3,4 p<0,05(p=0,002)$ for the telemarketer position than the speaker of the Transcarpathian-Hungarian version. However, they thought that each agent is convincing, helpful, kind, friendly, reliable and serious, and they also evaluated their pronunciation and tone positively. Based on the data we can also see that the participants judge the speakers with Ukrainian and Russian borrowed words better, in connection with those characteristics, which represent social connections (kindness, helpfulness) (Graphs 4 and 5). 
Anita Kiss:

A comparative analysis about the language attitude of Transcarpathian-Hungarian students with matched guise technique Argumentum 18 (2022), 1-16

Debreceni Egyetemi Kiadó DOI: 10.34103/ARGUMENTUM/2022/1

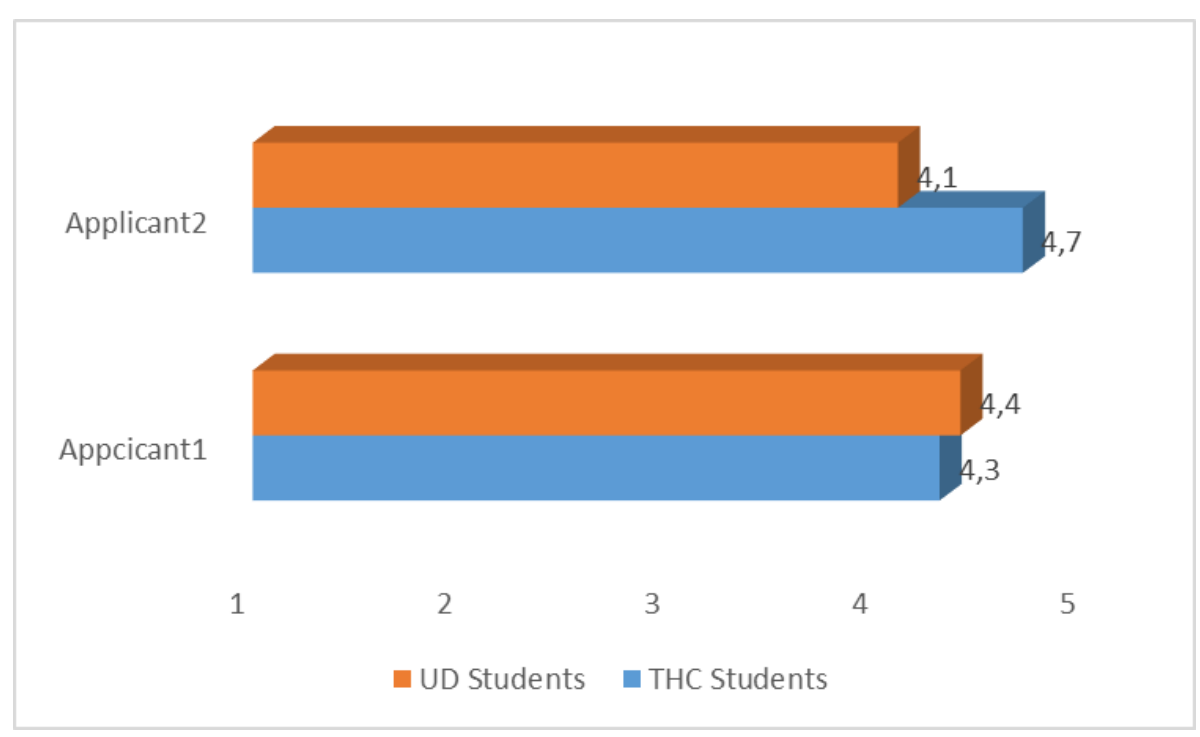

Graph 4. In what extent do you think the applicant is friendly?

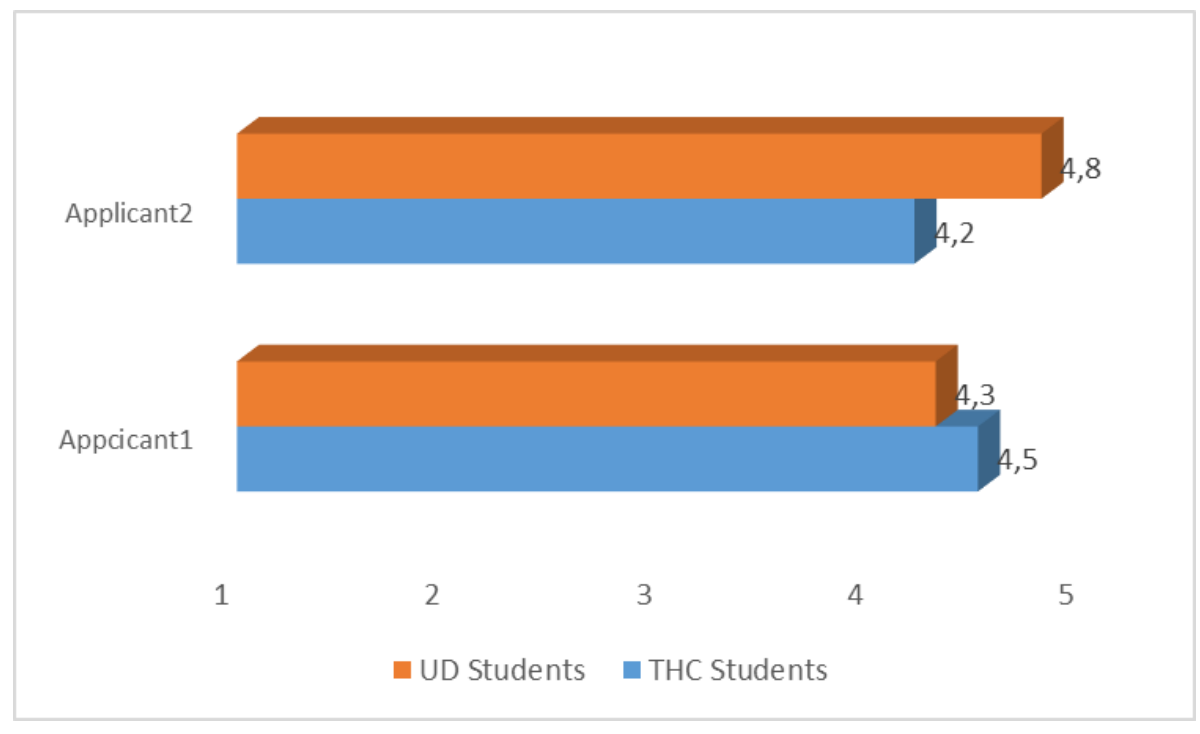

Graph 5. In what extent do you think the applicant is helpful?

Based on the answers of UD students, there was a significant difference only in two cases in the judgement of the two agents. The style of speech/vocabulary of the agent in the Hungarian version $\mathrm{t}(57)=3 \mathrm{p}<0,05(\mathrm{p}=0,003)$ was evaluated more positively, and the students also considered this person more suitable $t(56)=2,48 p<0,05(p=0,01)$ for the telemarketer position than the applicant using borrowed words from Ukrainian and Russian.

According to the other aspect of analysis I examined if there are considerable discrepancies between the judgments of the two participant groups towards the agent speaking in the Transcarpathian-Hungarian version. There were substantial differences between the two groups in connection with five characteristics. THC students evaluated the style of speech/vocabulary 
Anita Kiss:

A comparative analysis about the language attitude of Transcarpathian-Hungarian students

with matched guise technique

Argumentum 18 (2022), 1-16

Debreceni Egyetemi Kiadó

DOI: 10.34103/ARGUMENTUM/2022/1

$\mathrm{t}(41)=-3,6 \mathrm{p}<0,05(\mathrm{p}=0,000)$ of the speaker in the Transcarpathian-Hungarian version, as well as his pronunciation, phraseology, tone and they also considered the agent more serious.

The students were asked to evaluate, how important and distinguished the job of a telemarketer is. I found this question important, because as an alibi, I wanted to find a job that does not have a high prestige, because in a job like that the use of a standard version would be required. The opinion of the participants about the job's appreciation was what I expected. Both participant groups considered telemarketing as a moderately important and distinguished job (Graph 6).

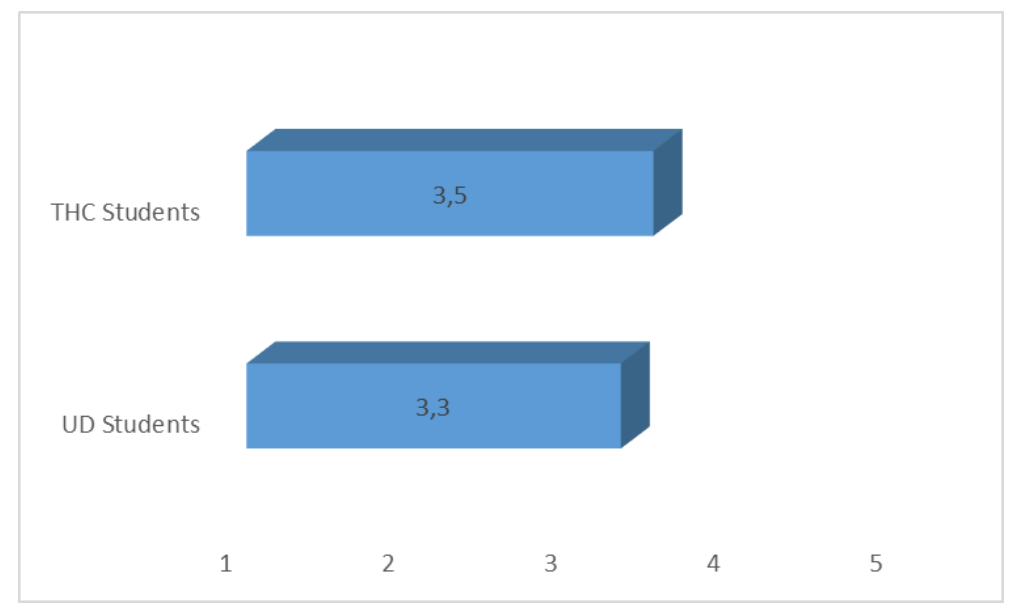

Graph 6. How important is telemarketing in your opinion?

The participants also had to tell, how suitable the candidate for the position is. Both groups of participants chose the speaker of the Hungarian version more suitable, but they do not think that the Transcarpathian-Hungarian agent would be unsuitable (Graph 7). It turned out that most participants would employ the agent for the position (Graph 8). The results show that the students evaluated the speaker of the Hungarian version better, but they did not have a negative opinion about the Transcarpathian-Hungarian speaker either. It shows that the participants do not have negative attitudes towards the use of borrowed words from Russian and Ukrainian.

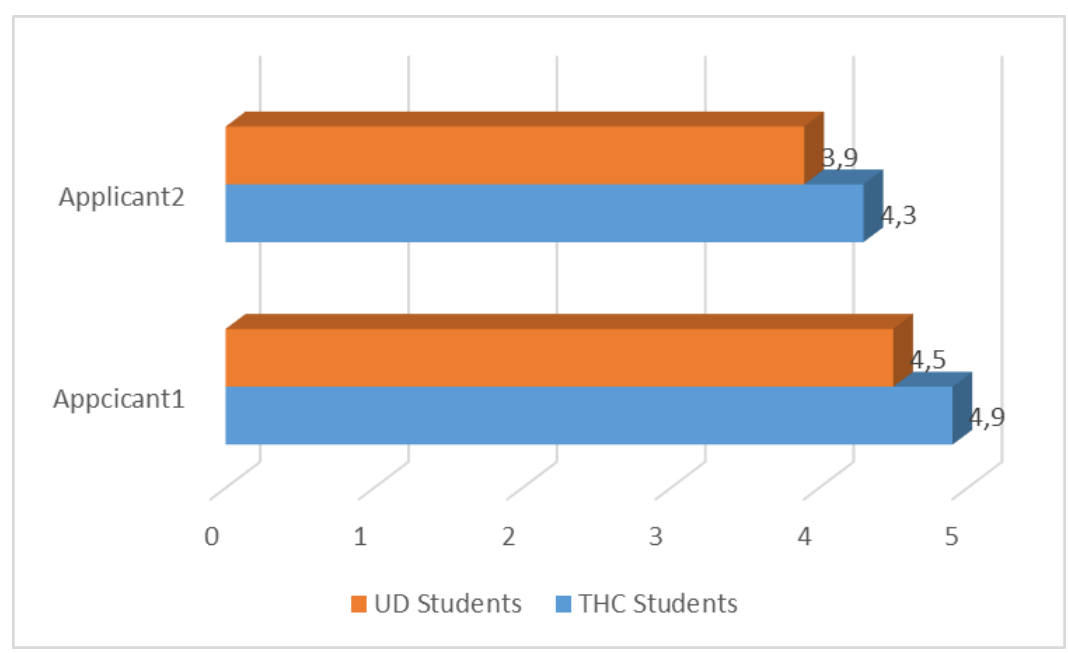

Graph 7. How suitable is the applicant for the job? 
Anita Kiss:

A comparative analysis about the language attitude of Transcarpathian-Hungarian students

with matched guise technique

Argumentum 18 (2022), 1-16

Debreceni Egyetemi Kiadó

DOI: 10.34103/ARGUMENTUM/2022/1

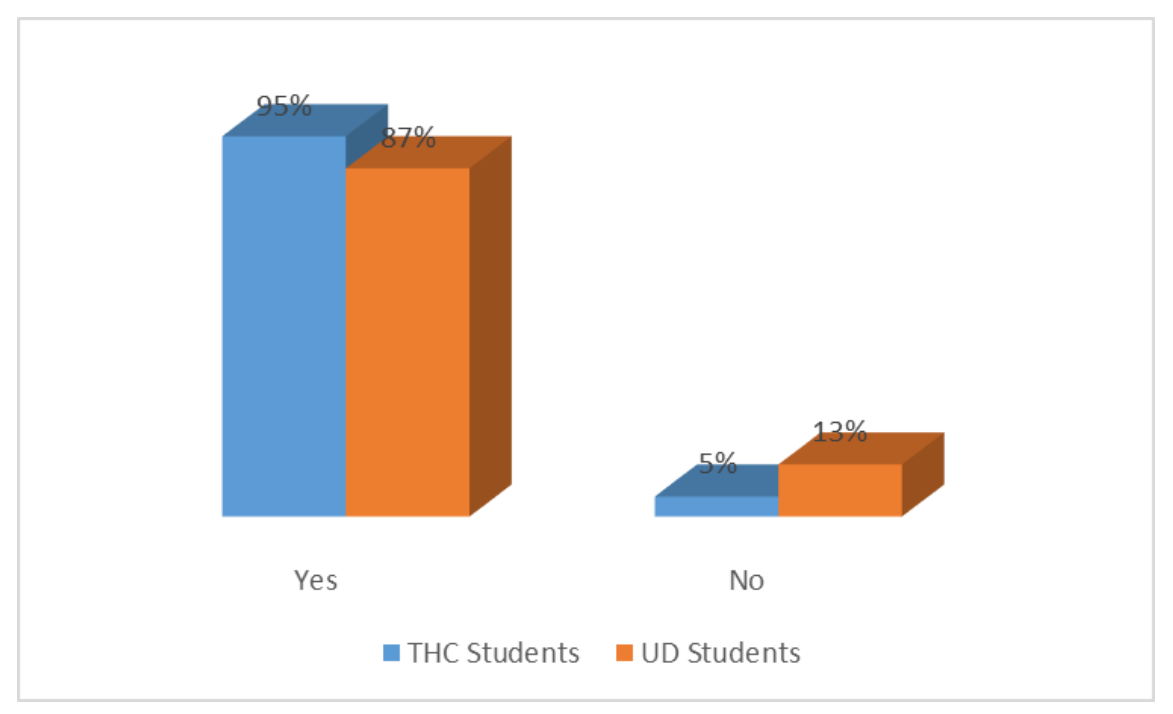

Graph 8. Would you employ the applicant as a telemarketer in Hungary?

\section{Conclusions}

The aim of my research was to discover the attitudes of Transcarpathian-Hungarian students towards the use of borrowed words from Ukrainian and Russian. I carried out the research with the help of matched guise technique. Transcarpathian-Hungarian students, studying in Hungary or Transcarpathia were involved in the research, with which I wanted to ascertain if the university and college students have a better attitude towards the agent speaking in a Hungarian or Transcarpathian-Hungarian language variant. On the other hand, I was also looking for the answer whether the students studying in Hungary or in Transcarpathia have a more positive opinion about the applicant (agent) using the Transcarpathian-Hungarian variant.

The hypotheses of the research have been confirmed, and the conclusions are consistent with the earlier results. During the survey the students were asked to evaluate the speakers (agents) based on characteristics connected to social behaviour (friendly, kind, helpful), personal features (serious, determined), competency (intelligent/smart, convincing, reliable) and language skills. According to the results, in relation to most of the characteristics, the students had a better opinion about the speaker of the Hungarian variant, and the differences between the judgement of the two agents were the most significant regarding to the language skills. $\left(1^{\text {st }}\right.$ hypothesis). This result is partly consistent with the conclusions of the Hungarian research carried out by Sándor, Langmann \& Pléh with the use of matched guise technique, because these also showed that the standardly speaking agent was judged more positively by the participants in connection with all the characteristics (compare Sándor, Langman \& Pléh 1998). Partially we can also find discrepancies between the two surveys, because in the study of Sándor, Langman \& Pléh the standard speaker was evaluated more positively in connection with the characteristics related to social skills as well. In my own research, UD students evaluated the agent speaking in the Transcarpathian-Hungarian version more helpful, while THC students thought that they are friendlier than the speaker in the Hungarian variant. It can be connected to Lambert's results, which showed that the non-standard speaker was judged 
Anita Kiss:

A comparative analysis about the language attitude of Transcarpathian-Hungarian students

with matched guise technique

Argumentum 18 (2022), 1-16

Debreceni Egyetemi Kiadó

DOI: 10.34103/ARGUMENTUM/2022/1

more positively than the standard speaker, in connection with some characteristics (e.g., kindness and friendliness) (Lambert et al. 1967).

To conclude, the students of the Transcarpathian-Hungarian college didn't judge negatively the speaker who used Ukrainian and Russian borrowed words. The participants, especially the students of the University of Debrecen, recognized, when the speakers here and there used nonHungarian words, which proves that they evaluated the agent's use of words the most negatively. According to the results it also comes to light that the participant's group learning in Transcarpathia evaluated each agent generally more positively than the TranscarpathianHungarian students learning in Hungary ( $2^{\text {nd }}$ hypothesis).

The most outstanding difference between the attitudes of the two groups is that the college students from Transcarpathia evaluated the Transcarpathian-Hungarian use of language more positively than the Transcarpathian students from the Hungarian university. Based on these results, we can draw the conclusion that the students neither from Transcarpathia, nor from Hungary evaluate the Ukrainian and Russian borrowed words appearing in the TranscarpathianHungarian version more negatively. At the same time, THC students have a more positive attitude towards the use of borrowed words than UD students.

\section{References}

Agheyisi, R. \& Fishman, J. (1970): Language attitude studies: A brief survey of methodological approaches. Anthropological Linguistics 12, 131-157.

Baker, C. (1992): Attitudes and language. Clevedon: Multilingual Matters.

Beregszászi, A., Csernicskó, I., Hires, K. \& Márku, A. (2003): Attitüdök és sztereotípiák: milyennek látjuk magunkat és az ukránokat? In: Csernicskó, I. (szerk.): A mi szavunk járása. Bevezetés a kárpátaljai magyar nyelvhasználatba. Ungvár: PoliPrint Kft.

Callan, V., Gallois, C. \& Forbes, P. (1983): Evaluative reactions to accented English. Journal of Cross-Cultural Psychology 14, 407-426. https://doi.org/10.1177/0022002183014004002

Cseresnyési, L. (2004): Nyelvek és stratégiák avagy a nyelv antropológiája. Budapest: Tinta Könyvkiadó.

Csernicskó, I. (2008): Nyelv és azonosságtudat összefüggései a kárpátaljai magyar közösségben. In: Fedinec, Cs. (szerk.): Értékek, dimenziók a magyarságkutatásban. Budapest: Magyar Tudományos Akadémia Magyar Tudományosság Külföldön Elnöki Bizottság, 153-170.

Csernicskó, I. \& Soós, K. (2002): Gyorsjelentés - Kárpátalja. In: Mozaik 2001. Magyar fiatalok a Kárpát-medencében. Budapest: Nemzeti Ifjúságkutató Intézet, 91-135.

Domonkosi, Á. (2004): A nyelvi attitüdök és a nyelvhasználat szabályozottsága. In: Kurtán, Zs. \& Zimányi, Á. (szerk.): A nyelvek vonzásában. Köszöntő kötet Budai László 70. születésnapjára. Eger, Veszprém: Veszprémi Egyetemi Kiadó, 25-31.

Dudics Lakatos, K. (2015): A nemek és a nyelvjárási attitüd összefüggéseiről egy kérdőíves felmérés tükrében. In: Márku, A. \& Hires-László, K. (szerk.): Nyelvoktatás, kétnyelvüség, nyelvi tájkép. Tanulmányok a Hodinka Antal Nyelvészeti Kutatóközpont kutatásaiból. Ungvár: Autdor-Shark, 34-43.

Dudics Lakatos, K. (2019): Kárpátaljai magyar pedagógusok nyelvjárási attitűdjének alakulása két felmérés eredményei alapján. Magyar Nyelvjárások 57, 123-134. 
Anita Kiss:

A comparative analysis about the language attitude of Transcarpathian-Hungarian students with matched guise technique

Argumentum 18 (2022), 1-16

Debreceni Egyetemi Kiadó

DOI: 10.34103/ARGUMENTUM/2022/1

Dudics, K. (2021): Kárpátaljai magyar iskolások nyelvjárási attitüdjének alakulása egy megismételt kérdőíves gyüjtés alapján. Magyar Nyelv 117/3, 346-354.

https://doi.org/10.18349/MagyarNyelv.2021.3.346

Fenyvesi, A. (2011): Nyelvi attitüdök kisebbségi kontextusban: erdélyi, vajdasági és felvidéki magyar diákok viszonyulása anyanyelvükhöz, az államnyelvhez és az angolhoz. In: HiresLászló, K., Karmacsi, Z. \& Márku, A. (szerk.): Nyelvi mitoszok, ideológiák, nyelvpolitika és nyelvi emberi jogok Közép-Európában elméletben és gyakorlatban. Beregszász, Budapest: II. Rákóczi Ferenc Kárpátaljai Magyar Főiskola Hodinka Antal Intézet, 227-234.

Gallois, C. \& Callan, V. (1981): Personality impressions elicited by accented English speech. Journal of Cross-Cultural Psychology 12, 347-359. https://doi.org/10.1177/0022022181123006

Gazdag, V. (2021): Szláv elemek a kárpátaljai Beregszászi járás magyar nyelvjárásaiban. Törökbálint: Termini Egyesület.

Giles, H. \& Coupland, N. (1991): Language: Contexts and consequences. Milton Keynes: Open University Press.

Grin, F. (2013): Language Policy, Ideology, and Attitudes. In: Bayley, R., Richard C. \& Ceil L. (ed.): The Oxford Handbook of Sociolinguistics. Oxford: University Press, 629-650.

Jánk, I. (2017): Nyelvi hátrány és diszkrimináció az iskolában: A nyelvi szocializáció jelentősége a tanuló értékelésében. Szociológiai Szemle 27/3, 27-47.

Jánk, I. (2018): A nyelvi alapú diszkrimináció vizsgálatának módszertani korlátai és lehetőségei. Magyar Nyelvör 142/2, 150-169.

Jánk, I. (2019): Lingvicizmus a Kárpát-medence négy országának gyakorló és leendő magyartanárainál. Magyar Nyelvör 143/1, 31-46.

Karmacsi, Z. (2009): Nyelvi attitüd: gyengítő és erősítő tényezők Kárpátalján a magyar nyelv esetében. In: Borbély, A., Vančoné Kremmer, I. \& Hattyár, H. (szerk.): Nyelvideológiák, attitüdök és sztereotípiák. Budapest, Dunaszerdahely, Nyitra: MTA Nyelvtudományi Intézet, Gramma Nyelvi Iroda, Konstantin Filozófus Egyetem Közép-európai Tanulmányok Kara, 415-422.

Kiss, J. (1995): Társadalom és nyelvhasználat. Budapest: Nemzeti Tankönyvkiadó.

Kožík, D. (2004): A nyelvjárásokkal kapcsolatos attitüdvizsgálatok a szlovákiai magyar pedagógusok néhány csoportjában. In: Lanstyák, I. \& Menyhárt, J. (szerk.): Tanulmányok a kétnyelvüségröl II. Pozsony: Kalligram.

Lakatos, K. (2006): A nyelvjárások megítélése kárpátaljai iskolások körében. Magyar Nyelvjárások 45, 97-104.

Lambert, W., Hodgson, R., Gardner, R. C. \& Fillenbaum, S. (1967): Evaluational reactions to spoken languages. Journal of Abnormal and Social Psychology 60, 44-51. https://doi.org/10.1037/h0044430

McKenzie, R. M. (2008): Social factors and non-native attitudes towards varieties of spoken English. A Japanese case study. International Journal of Applied Linguistics 18, 63-88. https://doi.org/10.1111/j.1473-4192.2008.00179.x

Milroy, L. \& Dennis, R. P. (1999): Introduction to special issue on language attitudes. Journal of Language and Social Psychology 18, 4-9. https://doi.org/10.1177/0261927X99018001001

Sándor, K. (2016): Nyelv és társadalom. Budapest: Krónika Nova.

Sándor, K., Langman, J. \& Pléh, Cs. (1998): Egy magyarországi ügynökvizsgálat tanulságai. (A nyelvváltozatok hatása a személypercepcióra). Valóság 8, 29-40. 
Anita Kiss:

A comparative analysis about the language attitude of Transcarpathian-Hungarian students with matched guise technique

Argumentum 18 (2022), 1-16

Debreceni Egyetemi Kiadó

DOI: 10.34103/ARGUMENTUM/2022/1

T. Károlyi, M. (2002): A nyelvi tudatosság és attitüd vizsgálata a beregszászi főiskola hallgatóinak különböző csoportjaiban. In: Hoffmann, I., Juhász, D. \& Péntek, J. (szerk.): Hungarológia és dimenzionális nyelvszemlélet. Debrecen: Debreceni Egyetem Magyar Nyelvtudományi Tanszék. 329-338.

Trudgill, P. (1997): Bevezetés a nyelv és társadalom tanulmányozásába. Szeged: JGYTF.

Anita Kiss

University of Nyíregyháza, Department of Hungarian Linguistics

Institute of Languages and Literature

4400 Nyíregyháza, Sóstói út 31/b.

anita.kiss@nye.hu 